\author{
В.А. Маслова
}

\title{
СИМВОЛ, ОБРАЗ, МЕТАФОРА, АЛЛЕГОРИЯ КАК СРЕДСТВА ПОСТИЖЕНИЯ «ПРЕКРАСНОГО» В ПОЭЗИИ ФРАНЦУЗСКОГО СИМВОЛИЗМА
}

\begin{abstract}
Аннотация. Предметом исследования является анализ и применение таких понятий, как символ, образ, метафора и аллегория в контексте совокупностей приёмов, средств и методов выражения «прекрасного» в поэзии французского символизма. Раскрывается эта тема, отталкиваясь от феноменологической природы "прекрасного», а также его понимания в рамках категории, определяемой классической эстетикой. Показывается также трансформация понимания «прекрасного», в частности красоты, и причины таких изменений. Рассматривается данная проблематика у таких авторов, как С. Малларме и Ш. Бодлер.

Используются следующие методы проведения исследования - множество комбинаторных совокупностей, таких как: анализ, компаративный (сравнительный) анализ темы исследования, применение символических образов, метафоричность и аллегоричность поэтики выражения "прекрасного» в поэзии французского символизма. Также используется анализ, синтез и аналогия, так как мы пытаемся встроить методы выражения и постижения прекрасного в рамках научной дисциплины эстетики.

Особым вкладом автора в исследование темы является то, что доказывается на основе лексической базы: средствами выражения и постижения «прекрасного» в поэзии французского символизма могут являться символ, образ, метафора и аллегория. Показывается новое понимание этих понятий в рамках эстетики франиузского символизма.
\end{abstract}

Ключевые слова: аллегория, символ, образ, прекрасное, метафора, французский символизм, Бодлер, Малларме, поэзия, эстетика.

Abstract. The subject of this research is the analysis and application of such notions as symbol, image, metaphor and allegory as part of a set of tools, means and methods of expressing 'beauty' in the French symbolist poetry. This subject is developed and based on the phenomenological nature of 'beauty' as well as in terms of the aesthetic category by means of defining it within both implicit and explicit aesthetics. The very problem of 'beauty' is represented in the poetry of French symbolism, in works of such authors as S. Mallarmé and Ch. Baudelaire. Conclusions on the means of expressing 'beauty' in the French symbolist poetry are presented at the end of the article. As far as methods of the research are concerned, there is a variety of combinative totals, such as analysis, comparative analysis, informationanalytical base of investigating the subject of the research, application of symbolic images, metaphoricalness and allegoricalness of the poetics of expressing 'beauty' in the French symbolist poetry. The author's particular contribution to the research on the subject is proving the fact - proceeding from the lexical base - that symbol, image, metaphor and allegory are the means of expressing 'beauty' in the French symbolist poetry.

Key words: poetry, Mallarme, Baudelaire, French symbolism, metaphor, beauty, image, symbol, allegory, aesthetics.

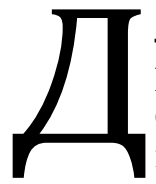

ля того чтобы раскрыть символ, метафору и аллегорию в контексте совокупности средств постижения и выражения «прекрасного» мы будем основываться на утверждении: произведения подлинного искусства всегда символичны. Для представителей французского символизма эта идея становится ключевой в их творчестве, хотя они развивают её по-разному в своих практических и теоретических работах. Более того, представители этого направления приходят к выводу, что поэзия не только содержат символы, но что и любое произведение искусства является символом. Художник всегда создаёт символы, но бессознательно, без своей воли. Но что такое «символ»? Стоит более подробно остановиться на определении сущностного смысла каждого из этих понятий: символ, метафора, аллегория, образ и прекрасное.

Проблема символа как понятия станет одной из ключевых в культуре и философии XX в. Именно поэтому определение и сужение ряда смыслов такого термина представляется достаточно сложным.

Самые важные работы по этой теме, проблемы происхождения символа и его природы, его 


\section{Философия и психология}

отличий от разнообразных форм эстетического выражения и семантических категорий (как знак, метафора, аллегория, художественный образ) мы найдём у Э. Кассирера, А.Ф. Лосева, А. Бергсона, Х.Г. Гадамера, Ж. Лакана, С. Лангер, К.А. Свасьяна и многих других. Исследователи выделяют различные общие черты в понимании символа, в зависимости от подходов, которые соответствуют разным научным школам. Понятие «символ» рассматривается в рамках философии культуры (Н.А. Бердяев, Й. Хёйзинга), философской герменевтики (Г. Гадамер), психоанализа и аналитической психологии (3. Фрейд, Э. Фромм, К.Г. Юнг), философии языка (Л. Витгенштейн, Ж. Лакан), философии символических форм (Э. Кассирер), «метафорического символизма» (С. Лангер), постмодернизма (Ж. Бодрийяр, Ж. Делёз). Здесь следует отметить, что каждое направление использовало свои методы анализа [20]. Более того, до появления такого течения в искусстве как символизм, многие европейские философы обращались к понятию символа: Пифагор, Платон, Аристотель, Авиценна, Ф. Аквинский, Плотин, И. Кант, Г.В.Ф. Гегель, Ф. Шеллинг, И. Гёте и др.

Мы остановимся на понимании символа в рамках классической эстетики, в которой одним из подходов является изучение символа, напрямую связанное с поиском трансцендентных основ бытия, духовности. Именно такой подход осуществляли и символисты. Таким образом, символ «внутри образа представляет собой тот трудно вычленяемый на аналитическом уровне глубинный компонент, который целенаправленно возводит дух реципиента к духовной реальности, не содержащийся в самом произведении искусства» [12, с. 373]. Символ не поддаётся вербальному описанию, он создаёт для каждого человека своё поле смыслов, которое он получает в процессе эстетического восприятия. Именно к такому определению приходят французские символисты. Для них символ - «метафорическое выражение Универсума, указывающее на духовную реальность; это принцип сотворения мира, и способ поэтического творчества, свидетельствующий о божественной функции поэтасимволиста - провидца, приобщённого к высшей реальности» $[18$, с. 22]. Более того, символ ещё может определяться как «выражающий некий сугубо духовный феномен, призванный пробудить эстетическую эмоцию, явить красоту (Рейно)» [18, c. 31]. Таким образом, с помощью символа постигается красота и выражается, но выражается она скорее через образ, так как символ в принципе невербализуем, но содержит в себе перво-Идею красоты.

В символизме категория образа понимается в системе множественных трактовок, и нет его единой концепции. В широком общефилософском плане образ - «субъективная копия объективной реальности. Художественный же образ - это образ, связанный с искусством, являющийся его целью и основой, сущностным ядром произведения искусства» [12, с. 362]. Образ также может пониматься как «визуальный образ», «зрительный образ», «изображение кого-либо или чего-либо». Для нашего рассмотрения в данной статье важен именно «художественный образ», трактуемый с точки зрения философско-эстетической составляющей творческого процесса любого жанра искусства, a, особенно, изобразительного искусства и поэзии [9]. Образ для французского символизма предстаёт как «символ целого, его творение, а не просто одна из частей. В каждом образе заключён символ «видимый аналог невидимой реальности» [1, p. 179]. Символ проступает в образе, как королевский профиль на монете; «он подобен ключу, чья конфигурация позволяет ему поворачиваться в замочной скважине, так как все зубчики и бороздки соответствуют язычку замка. Именно он - движущая сила, приводящая всё в действие» [18, с. 31].

«Метафора» в символизме прочитывается в виде средства, которое помогает выразить тот или иной образ, т.е., происходя от древнегреческого

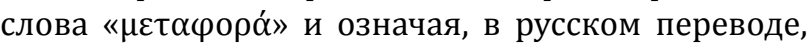
«перенос», «переносное значение».

Исходя из этого «метафора» как понятие, представляет собой совокупность характеристических свойств, мы остановимся на следующих, а именно:

- Свойство № 1 - «метафора» есть «категория» или «контекст»;

- Свойство № 2 - «метафора» являет собой некий объект в системе определенной категории;

- Свойство № 3 - «метафору» можно рассматривать и как процесс;

- Свойство № 4 - «метафора» в контексте такого процесса - есть определённые приложения самого этого процесса к конкретным обстоятельствам [8].

«Аллегория», происходящая от того же древ-

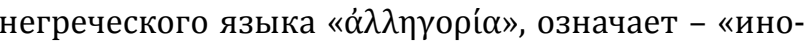
сказание», по сути дела, представляя собой совокупность художественных высказываний определённых идей через реальный «художественный образ», о котором мы говорили выше. Сама аллегория применяется как средство выражения «художественного образа» во многих жанpax искусства, a, особенно - в поэзии. Аллегория направлена на рассудочный уровень восприятия, а художественный образ и символ - на духовно- 


\section{Психология и психотехника 8(95) • 2016}

эстетическое. При этом символ направлен на более высокие уровни духовной реальности, чем образ и аллегория. Метерлинк в связи с этими различиями выделил две разновидности символизма: умозрительно-преднамеренный и бессознательный. Первый ближе к аллегории, так как создаётся из сознательного желания придать художественную форму сухой абстракции (Метерлинк ссылается здесь на вторую часть «Фауста» Гёте и его сказки); вся потенциальная энергия поэзии обернётся против того, кто «придумывает» символ. Второй же организует сокровенную энергию вещей, их тайную и вечную гармонию, питая такие гениальные произведения, как драмы Эсхила и Шекспира: «символ а priori возникает помимо воли поэта, а порой и вопреки ей: он присущ всем гениальным творениям человечества» [4].

В каком-то смысле именно они и выражают посредством себя понятие «прекрасного». Прежде всего, отметим, что эта дефиниция есть своеобразный феномен, форма неутилитарных субъект-объектных отношений. Т.е. то, что в широком философском смысле предстаёт перед нами в виде явления, которое проявляется в чувственном созерцании $[17$, с. 3]. В данном случае понятие «прекрасного» являют собой и ценности, и идеалы, и гармонию, и, особенно, красоту мира человека и его души. Такое понимание категории «прекрасного» начинает меняться в XIX в. Главные направления в искусстве этого столетия не являются ориентированными на «изящное искусство», о чём будет подробнее сказано дальше.

Далее стоит рассмотреть символ, образ, метафору и аллегорию как средства постижения и выражения «прекрасного» в особом понимании в поэзии французского символизма. Логика изложения такова:

- изменения, происходящие в системе общего категориального аппарата и, в частности, рассматриваемой в данной статье категории «прекрасного» во французском символизме конца XIX - начала XX вв.;

- сущность и содержание самой категории «прекрасного» в аксиологической системе теории Ш. Бодлера;

- развитие теории и практики французского символизма в творчестве С. Малларме: «прекрасное» в контексте совокупности средств его выражения.

Итак, прежде всего, рассмотрим изменения, происходящие в системе общего категориального аппарата и, в частности, рассматриваемой в данной статье категории «прекрасного» во французском символизме конца XIX - начала XX вв.
Эти изменения касаются, в первую очередь того обстоятельства, что само направление символизма появилось во второй половине XIX-го в. Оно возникло в силу отторжения «буржуазности» французской философии, а также таких течений, как позитивизм, реализм, морализм и рационализм, а также отвержения художественной культуры того исторического периода - академизма. Необходимо представить позиции основы зарождения и развития французского символизма на рубеже веков, на которых строилось изменение категорий. Именно в это время во французской литературе и, в целом, в искусстве назрела потребность в обновлении, в выработке нового искусства, соответствующей социально-политическим настроениям Франции. Век революций, завершившийся Парижской Коммуной 1871 г., активизировал и демократизировал французское общество. Между тем, было бы неправомерным утверждать, что возникновение данного течения обусловлено только социально-политическими факторами. Э. Кон-Винер в своей «Истории стилей изобразительных искусств» так писал: «...стиль не создаётся сознательно, но зависит от закономерных движений созидания и разрушения, от общего закона развития. Этот закон и является, быть может, сам по себе последней причиной» [15, с. 216].

Дефиниция «символизм» в контексте искусства был применён французским поэтом Ж. Мореасом в декларации, опубликованной в «Фигаро» 18 сентября 1886 г. под названием «Манифест символизма». Ж. Мореас, сам был поэтом, поэтому если мы посмотрим на данный термин в узком смысле, то он относится, конечно же, к литературным жанрам, а именно к поэзии. И только потом, с течением времени: «поэты-символисты, утвердившись как продуктивно работавшая в течение ряда лет стилистическая структура с явными лидерами, принялись искать художников, которые могли бы распространить их программу на другие области художественного творчества» [5, р. 51].

Ж. Мореас отразил, безусловно, общее настроение поэтов-символистов в манифесте, которые пытались отрицать всё, что было сделано до них: «Символическая поэзия - враг поучений, риторики, ложной чувствительности и объективных описаний; она стремится облечь Идею в чувственно постижимую форму, однако эта форма - не самоцель, она служит выражению Идеи, не выходя изпод её власти. С другой стороны, символическое искусство противится тому, чтобы Идея замыкалась в себе, отринув пышные одеяния, приготовленные для неё в мире явлений. Картины природы, человеческие деяния, все феномены нашей жизни значимы для искусства символов не сами по себе, а 


\section{Философия и психология}

лишь как осязаемое отражения перво-Идеи, указующие на своё тайное сродство с ними» [16].

В отличие от Ж. Мореаса Р. Этьемболь считал, что, данный «Манифест символистов» говорит лишь о том, что «идеализм символистов» происходит от категории «идеи» именно в философской сущности, а не в моральном основании этой категории [2].

Символисты считали, что всё множество природных оснований есть лишь «фикция» («видимость»), совершенно не обладающее идейным значимым художественным смыслом. Творчество всех различных символистов, принадлежащих к разным видам искусства, обосновывалось такими позициями, как: «недосказанность», «намёки», «таинственность», «загадочность» и т.д. И, поэтому, особенно поэзия, литературный текст, дающая множественность воображенных образов, символов и индивидуальности восприятия, играла ключевую роль в контексте методов представления и передачи символов.

В одной из главных работ по французскому символизму «Поэзия французского символизма. Лотреамон. Песни Мальдорора» Г.К. Косиков так сказал об этом явлении: «Предметный мир как таковой каждую секунду готов принять в себя тот или иной символический смысл, но сам он не есть этот смысл, ибо его можно представить себе вообще вне всякого смысла, как голую предметность» [16, с. 9].

П. Луи представил миру самый важный, на наш взгляд, принцип эстетики символизма, а именно: «Никогда не следует объяснять символы. Никогда не следует вникать в них. Имейте доверие. 0 , не сомневайтесь! Тот, кто придумал символ, скрыл в нём истину, но и не нужно, чтобы он её демонстрировал. Зачем тогда облекать её в символ?» [14, с. 185]. Можно сказать, что символисты осмысливают эти категории эстетики как символ, образ, метафора и аллегория, но в имплицитной форме. Нужно отметить, что, как правило, символисты довольно критически относились к натурализму Эмиля Золя, который считал, что философия и эстетика позитивизма «передаёт без искажений творческий дух современного искусства» [16, с. 429].

Главное значение сообщается суггестивной особенности поэтического жанра: мотиву, загадкам, грёзам, мечтам, снам, одиночеству, вечности, времени, которые используются далее «фовистами» и «сюрреалистами», и не только.

По сути дела, сама поэтика символизма во многом определяется принципом «non finite», а именно: «Художники в разных формах выражают идею незавершённости. Отказ от законченности даёт возможность расширить произведение за его физические пределы, обновляет технику художественного выражения» [4, p. 144].

Особую выразительность это высказывание приобрело в поэзии. Совершается революция жанра, ибо А. Рембо создаёт верлибр, новое видение системы стихосложения, представляющее собой своего рода границу между стихом и прозой, так как в ней отсутствует рифма, размер, классическая ритмическая упорядоченность; количество слогов в строке и строк в строфе может быть различно; отсутствует также равенство акцентов, свойственное белому стиху. Из особенностей стихотворной речи сохраняется деление на строки с паузой в конце каждой строки и ослабленная симметричность речи (ударение падает на последнее слово строки) [16].

Ранее П. Верлен сделал попытку трансформировать стихотворения «изнутри» и добиться главенствования ритма в рамках силлабизма. Но «верлибристы, т.е.: Ж. Кассу, П. Брюнель, Ф. Клодон, намерены идти дальше; они больше не занимаются только подсчётом слогов, важны единицы ритма, которые диктуются и направляются метром и соответствуют ему. Они надеются таким образом заменить “математический ритм" ритмом “психологическим”, более подходящим для воспроизведения внутреннего движения души» [14, с. 190].

Особенно важно для нас, что во французском символизме трансформируется и трактовка категории прекрасного. Поэтические деятели говорят именно о красоте, а не о прекрасном, что связано с основами эстетики символизма. В конце XIX в. идёт «последовательный процесс девальвации феномена и категории прекрасного как в теории, так и в художественной практике» [12, с. 280-281]. Ещё романтики начинают искать новые идеалы, они начинают обращаться к такой категории, как «безобразное», а также к теме Эроса и Танатоса как нерасторжимого единства, в котором они видят особую красоту, которая уже не имеет интенций к возвышенному прекрасному: «Прекрасное у романтиков - это всегда некий туманный шифр, загадка, тайна, ибо и сам романтический универсум непознаваемая тайна во всей своей неявности и многозначности» [22, с. 92]. Смерть наделяется ими красотой (например, в представлениях Леопарди, Китса, Ламартина).

Категория красоты как нельзя лучше подходит для эстетики символизма, потому что именно красота мыслится как характеристика универсума. Красота для символистов онтологична. Она является сущностной характеристикой универсума независимо от своей формы. Ш. Морис убеждён, что 


\section{Психология и психотехника 8(95) • 2016}

постижение красоты является важным этапом в поиске истины. А истина нужна для обретения мечты: «Мечта - та запредельная область, где свет высшей Истины, слепящий наши глаза с чересчур близкого расстояния, становится дальше и мягче и оттого глубже и богаче отголосками, которые звучат в нашем уме многократным эхом» [16, с. 433]. Символисты ищут истину в самой красоте, «выводя из законов гармонии не только метафизику (ибо гармония оттенков и звуков символизирует гармонию душ и миров), но и Мораль (ибо слово «честь» мы ведём от "honestus”, что означает "прекрасный”)» [16, с. 433-434]. Ш. Морис говорит о присущей красоте гармонии, он понимает красоту как некий первозданный закон существования. «Мечта, интуитивно предвосхищая будущее, славит неизбежное слияние Духа Религии и Духа Науки на Празднестве Красоты, проникнутом самым человеческим из желаний: обрести цельность, вернувшись к первозданной простоте» [16, с. 433].

Категория прекрасного предстаёт в системе категорий классической эстетики одной из главных, а категория красоты представляет собой всего лишь «одну из традиционных категорий эстетики, входящую в семантическое поле категории «прекрасное», по сути дела - «характеристику только эстетического объекта» [13, с. 254]. Безусловно, все люди, и в частности, поэты и художники, на протяжении всего своего существования, ставили перед собой вопрос: «Что есть “прекрасное" и что представляет собой категория “красоты”»? В разные эпохи люди по-разному отвечали на эти вопросы, как в имплицитной, так и в эксплицитной форме. Однако интересно, что В.П. Чинаев отмечает: «Культ самоценной красоты цвета, слова, звука становится константой символистской эстетики, фиксирующей, пожалуй, впервые в истории художественных эволюций Нового времени пристальный интерес к трансцендентной сущности Прекрасного» [22, с. 99].

Наиболее концентрированное выражение представления французских символистов о прекрасном нашли в их поэтическом творчестве. В данной работе мы сосредоточимся на анализе понимания категории прекрасного и красоты на примере творчества Ш. Бодлера и С. Малларме, наиболее репрезентативном в этом отношении.

Рассматривая категорию прекрасного в творчестве Ш. Бодлера, нужно отметить, что он подругому понимает категорию эстетики символизма - красоту, о чём было написано ранее. Он считает, что объектом поэзии может быть только сама поэзия, а не идеал, истина, вечность, разум: «Чистый разум стремится к Истине, эстетический вкус ищет Красоту, а моральное нравственное чувство научает нас Долгу» [10, с. 15].

Ш.Бодлер говорит о нескончаемом и бессмертном инстинкте прекрасного, который заставляет нас видеть в земле только намёк, отражение соответствий небесному, ибо только красота транслируется в поэзии и только поэтом. Это высказывание представляет собой общее основание для поэтов-символистов, так как именно они утверждают исключительную роль гения, поэта как проводника в иные миры, а именно: «Красоту и величие, скрытые за могилой, душа провидит в поэзии и через поэзию» [10, с. 15]. При этом фраза «скрытые за могилой» обозначает как идею о видении и поиска красоты в Танатосе, так и в прошлом, которое безвозвратно утрачено. Для нас это важно, потому что с проблемой прекрасного в эстетике символизма поэт упоминает и о времени. О. Харрингтон утверждает, что Ш. Бодлер одним из первых поставил вопрос о современности, и именно с его творчества мы можем говорить о понятии современного искусства, а именно: «Бодлер утверждает, что современным художникам не найти красоту в обычаях и традициях прошлого. Старые законы красоты больше не действуют» [3, p. 143].

Красота для Ш. Бодлера имеет характер двойственности и относительности, ибо в ней присутствует высшее начало, т.е. - «Перво-Идея» и историчность. Стихотворение «Красота» из сборника «Цветы зла» посвящено стремлению к высшей сверхчувственной красоте:

О смертный! как мечта из камня, я прекрасна! И грудь моя, что всех погубит чередой, Сердца художников томит любовью властно, Подобной веществу, предвечной и немой.

В лазури царствую я сфинксом непостижным; Каклебедь, я бела, и холодна, как снег; Презрев движение, любуюсь неподвижным; Вовекя не смеюсь, не плачуя вовек.

Я - строгий образец для гордых изваяний, И, с тщетной жаждою насытить глад мечтаний, Поэты предо мной склоняются во прах.

Но их ко мне влечёт, покорных и влюблённых, Сиянье вечности в моих глазах бессонных, Где всё прекраснее, как в чистых зеркалах.

(Перевод В. Брюсова)

Размышления Ш. Бодлера оказали весьма сильное влияние на культурологическую мысль в ХХ в. Ю. Хабермас связывает мысль Ш. Бодлера 


\section{Философия и психология}

с положением о современности как о времени, в котором общество приходит к осознанию своего прошлого как истории. Такой подход к проблеме времени становится особенно актуальным, когда относительность Эйнштейна заменяет абсолютное пространство Ньютона, а кубисты, сюрреалисты, футуристы и первые кинематографисты разрабатывают дробление, фрагментирование, одновременность и рациональность эксперимента.

Идея бинарности красоты проходит через всё творчество Ш. Бодлера. «Ужас перед жизнью и восторг жизни» - так определил сам Ш. Бодлер терзавшую его противоречивость. Это относится и к пониманию категории красоты. Бинарность в его творчестве имеется и в понимании красоты: «"Душа" открылась Бодлеру как средоточие Зла, причём Зла сладостного, затягивающего своей страшной “красотой” в бездонную “пучину”, где человек, давший себя соблазнить, платит за это своей “самостью”, нравственным единством личности» $[16$, с. 15$]$.

В стихотворении «Гимн красоте» поэт пишет о Красоте так:

Прислал ли ад тебя иль звёздные края? Твой Демон, словно пёс, с тобою неотступно; Всегда таинственна, безмолвна власть твоя, И всё в тебе - восторг, и всё в тебе преступно!

С усмешкой гордою идёшь по трупам ты, Алмазы ужаса струят свой блеск жестокий, Ты носишь с гордостью преступные мечты На животе своём, как звонкие брелоки.

Вот мотылёк, тобой мгновенно ослеплён, Летит к тебе - горит, тебя благословляя; Любовник трепетный, с возлюбленной сплетён, Как с гробом бледный труп сливается, сгнивая.

Будь ты дитя небес иль порожденье ада, Будь ты чудовище иль чистая мечта, В тебе безвестная, ужасная отрада! Ты отверзаешь нам к безбрежности врата.

Ты Бог иль Сатана? Ты Ангел иль Сирена? Не все ль равно: лишь ты, царица Красота, Освобождаешь мир от тягостного плена, Шлёшь благовония и звуки и цвета!

(Перевод А. Васик)

Существует два мира: сплин и идеал, зло и добро, есть также и два вида красоты: красота зла и красота добра. «Бодлеровская Красота... - это бесстрастное совершенство любого предмета независимо от его этического содержания: предмет может быть совершенным воплощением чистоты и невинности (“дитя небес"), но может быть и столь же совершенным воплощением разврата, нечестия и зла ("порожденье ада"). Бодлеровский “символический собор" не просветлён благодатью, в нём продолжается всё та же борьба между Богом и Сатаной, этот собор хотя и “устроен” вполне соразмерно, но всё же не благоустроен так, чтобы человеку было в нём уютно: его холодная, “как снег”, красота не может “спасти”, а сам переход в символическое измерение не только не разрешает бытийных конфликтов, но лишь сообщает им “торжественность” и придаёт “нечто от вечности”» [16, c. 16-17].

Это во многом новое понимание красоты. Если для романтиков безобразное также было источником вдохновения и темой для размышлений, то символисты превозносят красоту зла наравне с красотой добра. Красота в их эстетике не связана с моралью.

Темой специального исследования могут послужить бодлеровские «соответствия» - термин, который стал ключевым для французского символизма. Поэт, обладающий даром «соответствий», умеет открыть «тайной интуицией отношения, невидимые для других, и таким образом сблизить неожиданными аналогиями, которые может уловить только ясновидящий, предметы, на поверхностный взгляд самые далёкие и самые противоположные» [16, с. 21]. Принцип соответствий стал одним из ключевых для символистов, так как все вещи, фактически для них подключены к первоначалам вселенской жизни, и именно поэтому они начинают перекликаться, и звук, и запах, и форма, и цвет - в этот момент рождается синтез искусств, звуки и запахи окрашиваются, цвета приобретают музыкальное звучание, и все они «вовлекаются в общий хоровод взаимопревращений, требуя, чтобы их уловили в едином и мгновенном акте восприятия» $[16$, с. 17]). Но чтобы это произошло, всякий истинный поэт должен быть одарён в большей или меньшей степени ощущением таких «соответствий», составляющих, по мнению Ш. Бодлера, саму сущность искусства.

Благодаря символам, а в частности, образам и аллегориям, поэт может передать эту сущностную связь в своих творениях искусства. В каком-то смысле нахождение таких «соответствий» является выражением красоты и прекрасного. «Всматривание, вслушивание в красоту несуществующего, только измышленного, только рождённого тончайшим вкусом художника-эстета; едва ли не упое- 


\section{Психология и психотехника 8(95) • 2016}

ние гибко переменчивыми полутонами состояний, полное погружение в природу звука, цвета; неуловимость, тонкость градаций настроений, их гибкой вибрации и непредсказуемой ассоциативности, наконец, обращение к неканонической метафоричности, наполняющей пространство образа дополнительными смысловыми обертонами - всё это несло в себе одну и общую цель: выразить метафизическую тайну Прекрасного» [22, с. 98]. Об этом размышлял и С. Малларме: «Природа существует, и к ней ничего не добавить; <... Но одна возможность остаётся у нас всегда - возможность уловить связи между явлениями, ...вызывать к жизни порой прекрасные в своей многосмысленности образы» [16, с. 428].

Итак, рассмотрев изменения, происходящие в системе общего категориального аппарата и, в частности, рассматриваемой в данной статье категории прекрасного во французском символизме конца XIX в., а также, сущность и содержание самой категории прекрасного и красоты в аксиологической системе теории Ш. Бодлера, передаваемого с помощью определённых средств выражения его, а именно: символа, образа, метафоры и аллегории, далее мы переходим к анализу развития теории и практики французского символизма в творчестве С. Малларме. Ш. Бодлера позднее назовут «мозгом символизма», а С. Малларме оригинально развил многие его идеи и стал одним из ключевых теоретиков символизма, продолжателем его поэтической реформы, последователем его напряжённого субъективизма, его пессимистического, минорного взгляда на окружающую действительность, поэтому мы выбрали именно этих двух поэтов. В теоретических статьях, начиная с 1866 г., С. Малларме высказывает убеждение, что только поэт может проникнуть в тайны вселенной, ощутить внушение чистых, неясных звуков, воссоздать идеальные образы, «угадать узор, предвечно существующий в лоне Красоты» [16, с. 423] и перевести его на человеческий, таинственный язык.

По мнению С. Малларме, в поэзии важно «навеять» образ, а «назвать предмет - значит на три четверти разрушить наслаждение от стихотворения - наслаждение, заключающееся в самом процессе постепенного и неспешного угадывания; подсказать с помощью намёка - вот цель, вот идеал. Совершенное владение этим таинством как раз и создаёт символ; задача в том, чтобы, исподволь вызывая предмет в воображении, передать состояние души или, наоборот, выбрать тот или иной предмет и путём его медленного разгадывания раскрыть состояние души» $[16$, с. 425]. Искусство это что-то священное, своеобразная новая рели- гия, которая требует от поэта самоотверженности и служения. С. Малларме верил, что понимать прекрасное способны только избранные.

Влияние его на французскую поэзию было чрезвычайным. Он организовал в Париже интеллектуальный «кружок» для избранных - так называемые «вторники» Малларме в его квартире на Римской улице, 89, в котором обсуждались самые сложные проблемы поэтического творчества. Символисты негласно объявили С. Малларме своим лидером.

Концепция С. Малларме состоит в том, что первопричина всего, есть «Материя - Абсолют, из которого всё рождается и в котором всё погибает, где нет индивидуально оформленных вещей, все противоположности взаимоуничтожены, не существует ни верха, ни низа, ни права, ни лева, ни прошлого, ни будущего, но есть лишь неизбывная самотождественность и бесконечное настоящее - Вечность, или Ничто - “ничто, которое есть истина"» [16, с. 26]. Истина материи для поэта заключается в том, что она необходима, она не может распасться на разные явления, но только поэт может познать всю взаимосвязанность, «соответствия» мира, фактически, он развивает идеи Ш. Бодлера о «соответствиях». Такая материя, которая внутренне упорядочена, может быть обозначена как красота («После того как я нашёл Ничто, я нашёл Красоту», эта же фраза говорит и об онтологической основе и уникальной роли формы), передать которую способна только поэзия («Есть только Красота, и для неё существует лишь один совершенный способ воплощения - поэзия» $[16$, с. 26]). В понятие красоты может также входить и метрически совершенная форма. «Онтологическая схема (в письме едва означенная, позднее выраженная яснее) соотносит «ничто» (абсолют) и логос: именно в логосе обретает «ничто» свою духовную экзистенцию. Поэтические формы, согласно старой романской идее, суть проявление логоса. Отсюда можно объяснить фразу Малларме. Его поэзия, уничтожающая любую реальность, тем активнее взывает к «прекрасному», к формальной красоте языка. Эта формальная красота, обнимающая и метрические отношения, есть спасительный сосуд для «ничто» в объективном смысле» [21, с. 242].

Можно сказать, что красота есть всего лишь формальная упорядоченность Материи; она лишена нравственной наполненности, и у неё нет никакой цели - одна только внутренняя целесообразность. «Разработав технику суггестии, заставив читателя пережить наличную действительность не как нечто самодостаточное, но как “тайну”, требующую разгадки, искоренив в себе "нечистое я” субъективности и “предоставив инициативу словам”, которые под воздействием силовых ли- 


\section{Философия и психология}

ний Красоты должны послушно сложиться по её тончайшему узору, восторжествовав тем самым над Случайностью, Малларме надеялся подобрать “ключ” к универсуму и дать “орфическое объяснение Земли"» [16, с. 28]. С. Малларме, как и другие символисты, думали, что это по силам только поэтам, он считал, что существуют два сознания, и от одного из них - сознания «толпы» - красота скрыта. Эта мысль нашла и образное воплощение в его «Прозе для Дез Эссента». Подруга, которую поэт называет «сестрой», в конце поэмы рекомендует ему покинуть мир грёз, пробудиться от них, не покидать совсем обыденную жизнь, но при этом не оставлять в идеальном, абстрагированном мире, существующем вне конкретного времени года, гробницу с именем Высшей Красоты. Малларме строго придерживается принципа отбора средств словесного выражения. Затруднённость восприятия и размытость смысла непосредственно вытекает из того, что он предназначает свои произведения для избранной аудитории.

С. Малларме разрабатывает новый принцип в поэтике: «Рисовать не саму вещь, но впечатление, которое она производит» [6, р.206], что рождает совершенно новый язык. Причём интересно, что для С. Малларме впечатление - это момент, когда поэт соприкасается с Идеей предмета, с его символом, в отличие от мимолетного импрессионистического впечатления. Только новый язык, не описательный, а суггестивный язык (намекающий), где предметы начинают перетекать и превращаться друг в друга самым неожиданным образом. «Совершенное владение этим таинством как раз и создаёт символ» [16, с. 27]. Элементы вещного мира, привлекавшие внимание Бодлера, Верлена, Рембо, не играют существенной роли в образном строе произведений С. Малларме.

Таким образом, можно прийти к выводу, что французские символисты, начиная с Ш. Бодлера, но продолжая традицию романтиков, начали подругому воспринимать и выражать прекрасное, в частности идею красоты. В поэзии это отразилось в новой концепции эстетики французского символизма, а также некоторых средствах выражения и постижения «прекрасного»: символе, образе, метафоре и аллегории.

\section{Список литературы:}

1. $\quad$ Claudel P. Art poétique. 1907. P. 206.

2. Etiémble R. Le Mythe de Rimbaud: 3 vol. P.: Gallimard, 1968.

3. Harrington A. Art and social theory: sociological arguments in aesthetics. Cambridge: Polity Press Ltd. 2004. P. 237.

4. Huret. Enquete sur l'évolution littéraire // L’Echo de Paris. Février, 1891.

5. $\quad$ Lucie-Smith E. Le Symbolisme. Paris: Editions Thames \& Hudson SARL, 1999. P. 216.

6. Mallarmé S. Correspondance complète (1862-1871) suivi de lettres sur la poésie (1872-1898). Gallimard, 1995. P. 688.

7. $\quad$ Rapetti R. Le symbolisme. Paris: Flammarion, 2005. 318 p.

8. Анкерсмит Ф.Р. История и тропология: взлёт и падение метафоры / Пер. с англ. М. Кукарцева, Е. Коломоец, В. Кашаев. М.: Прогресс-Традиция, 2003. 496 с.

9. Беляев Н.И. Образ человека в изобразительном искусстве: индивидуальное и типичное // Вестник Оренбургского государственного университета. 2007. № 7. С. 175-179.

10. Бодлер Ш. Об искусстве. М.: Искусство, 1986. 421 с.

11. Бодлер Ш. Цветы зла / Пер. В. Брюсова. [Электронный ресурс] URL: http://www.world-art.ru/lyric/lyric.php?id=17520.

12. Бычков В.В. Эстетическая аура бытия. Современная эстетика как наука и философия искусства. М.: Изд-во МБА, 2010. $784 \mathrm{c}$.

13. Бычков В.В., Бычков О.В. Прекрасное // Лексикон нонклассики. Художественно-эстетическая культура ХХ века / Под ред. В.В. Бычкова. М.: Российская политическая энциклопедия (РОССПЭН), 2003.

14. Кассу Ж., Брюнель П., Клодон Ф. и др. Энциклопедия символизма: Живопись, графика и скульптура. Литература. Музыка. М.: Республика, 1999. 429 с.

15. Кон-Винер Э. История стилей изобразительных искусств. М.: Изд-во В. Шевчук, 2001. С. 217.

16. Косиков Г.К. Два пути французского постромантизма: символисты и Лотреамон // Поэзия французского символизма. Лотреамон. Песни Мальдорора. М.: Изд-во МГУ, 1993. 507 с.

17. Лотман Ю.М. Предисловие // Столович Л.Н. Красота. Добро. Истина. Очерк истории эстетической аксиологии. М.: Республика, 1994. 464 с.

18. Маньковская Н.Б. Эстетическое кредо французского символизма // Эстетика: Вчера. Сегодня. Всегда. Вып. 5. М.: ИФ РАН, 2012. 184 с.

19. Михайлов К.А. Феномен // Новая философская энциклопедия: в 4 т. T. IV. М.: Мысль, 2010. 736 c.

20. Спирова Э.М. Философско-антропологическое содержание символа. М.: Канон+ РООИ «Реабилитация», 2012.336 с.

21. Фридрих Г. Структура современной лирики: от Бодлера до середины двадцатого столетия / Пер. Евг. Головина. М.: Языки славянских культур, 2010. 342 с.

22. Чинаев В.П. Метаморфозы Прекрасного в художественных дискурсах прошлого и настоящего // Философский журнал. 2014. № 2 (13). С. 88-120.

23. Шабанова H.A. Словарь литературоведческих терминов. Инта, Республика Коми, 2008. [Электронный ресурс] URL: http://www.textologia.ru/slovari/literaturovedcheskie-terminy/verlibr/?q=458\&n=38. 


\section{Психология и психотехника 8(95) • 2016}

24. Спирова Э.М. Феномен символа в истолковании человека // Философия и культура. 2012. № 2. С. $42-50$.

25. Лавренова О.А. Семантика культурного ландшафта: от географических образов к знакам // Философия и культура. 2010. № 12. С. 63-72.

26. Букреева А.Н. Эпистемологические аспекты символики визуального художественного образа // Философия и культура. 2014. № 12. С. 1834-1844. DOI: 10.7256/1999-2793.2014.12.11374.

27. Спирова Э.М. Символ как образ и понятие (Полемический отклик на замечания проф. В.А. Подороги) // Философия и культура. 2012. № 6. С. 96-105.

28. Ковальчук А.М. Символ и символизация: статичность явления, динамичность процесса // Философия и культура. 2013. № 9. C. 1281-1287. DOI: 10.7256/1999-2793.2013.9.9284.

\section{References (transliterated):}

1. Claudel P. Art poétique. 1907. P. 206.

2. Etiémble R. Le Mythe de Rimbaud: 3 vol. P.: Gallimard, 1968.

3. Harrington A. Art and social theory: sociological arguments in aesthetics. Cambridge: Polity Press Ltd. 2004. P. 237.

4. Huret. Enquete sur l'évolution littéraire // L’Echo de Paris. Février, 1891.

5. Lucie-Smith E. Le Symbolisme. Paris: Editions Thames \& Hudson SARL, 1999. P. 216.

6. Mallarmé S. Correspondance complète (1862-1871) suivi de lettres sur la poésie (1872-1898). Gallimard, 1995. P. 688.

7. Rapetti R. Le symbolisme. Paris: Flammarion, 2005. 318 p.

8. Ankersmit F.R. Istoriya i tropologiya: vzlet i padenie metafory / Per. s angl. M. Kukartseva, E. Kolomoets, V. Kashaev. M.: Progress-Traditsiya, 2003. 496 s.

9. Belyaev N.I. Obraz cheloveka v izobrazitel'nom iskusstve: individual'noe i tipichnoe // Vestnik Orenburgskogo gosudarstvennogo universiteta. 2007. № 7. S. 175-179.

10. Bodler Sh. Ob iskusstve. M.: Iskusstvo, 1986. $421 \mathrm{~s}$

11. Bodler Sh. Tsvety zla / Per. V. Bryusova. [Elektronnyi resurs] URL: http://www.world-art.ru/lyric/lyric.php?id=17520.

12. Bychkov V.V. Esteticheskaya aura bytiya. Sovremennaya estetika kak nauka i filosofiya iskusstva. M.: Izd-vo MBA, 2010.784 s.

13. Bychkov V.V., Bychkov O.V. Prekrasnoe // Leksikon nonklassiki. Khudozhestvenno-esteticheskaya kul'tura XX veka / Pod red. V.V. Bychkova. M.: Rossiiskaya politicheskaya entsiklopediya (ROSSPEN), 2003.

14. Kassu Zh., Bryunel' P., Klodon F. i dr. Entsiklopediya simvolizma: Zhivopis', grafika i skul'ptura. Literatura. Muzyka. M.: Respublika, 1999. 429 s.

15. Kon-Viner E. Istoriya stilei izobrazitel'nykh iskusstv. M.: Izd-vo V. Shevchuk, 2001. S. 217.

16. Kosikov G.K. Dva puti frantsuzskogo postromantizma: simvolisty i Lotreamon // Poeziya frantsuzskogo simvolizma. Lotreamon. Pesni Mal'dorora. M.: Izd-vo MGU, 1993. 507 s.

17. Lotman Yu. M. Predislovie // Stolovich L.N. Krasota. Dobro. Istina. Ocherk istorii esteticheskoi aksiologii. M.: Respublika, 1994. $464 \mathrm{~s}$.

18. Man'kovskaya N.B. Esteticheskoe kredo frantsuzskogo simvolizma // Estetika: Vchera. Segodnya. Vsegda. Vyp. 5. M.: IF RAN, 2012.184 s.

19. Mikhailov K.A. Fenomen // Novaya filosofskaya entsiklopediya: v 4 t. T. IV. M.: Mysl', 2010. 736 s.

20. Spirova E.M. Filosofsko-antropolgicheskoe soderzhanie simvola. M.: Kanon+ ROOI «Reabilitatsiya», $2012.336 \mathrm{~s}$.

21. Fridrikh G. Struktura sovremennoi liriki: ot Bodlera do serediny dvadtsatogo stoletiya / Per. Evg. Golovina. M.: Yazyki slavyanskikh kul'tur, 2010. $342 \mathrm{~s}$.

22. Chinaev V.P. Metamorfozy Prekrasnogo v khudozhestvennykh diskursakh proshlogo i nastoyashchego // Filosofskii zhurnal. 2014. № 2 (13). S. 88-120.

23. Shabanova N.A. Slovar' literaturovedcheskikh terminov. Inta, Respublika Komi, 2008. [Elektronnyi resurs] URL: http://www. textologia.ru/slovari/literaturovedcheskie-terminy/verlibr/?q=458\&n=38.

24. Spirova E.M. Fenomen simvola v istolkovanii cheloveka // Filosofiya i kul'tura. 2012. № 2. S. 42-50.

25. Lavrenova O.A. Semantika kul'turnogo landshafta: ot geograficheskikh obrazov k znakam // Filosofiya i kul'tura. 2010 . № 12. S. 63-72.

26. Bukreeva A.N. Epistemologicheskie aspekty simvoliki vizual'nogo khudozhestvennogo obraza // Filosofiya i kul'tura. 2014. № 12. S. 1834-1844. DOI: 10.7256/1999-2793.2014.12.11374.

27. Spirova E.M. Simvol kak obraz i ponyatie (Polemicheskii otklik na zamechaniya prof. V.A. Podorogi) // Filosofiya i kul'tura. 2012. № 6. S. 96-105.

28. Koval'chuk A.M. Simvol i simvolizatsiya: statichnost' yavleniya, dinamichnost' protsessa // Filosofiya i kul'tura. 2013 . № 9. S. 1281-1287. DOI: 10.7256/1999-2793.2013.9.9284. 